\title{
BODOČNOST MEST - VPLIV GLOBALIZACIJE IN REGIONALIZACIJE KOT MOTEČA ELEMENTA
}

Mednarodni medinštitutski seminar Oddelkov za geografijo Filozofske fakultete v Ljubljani in Inštituta za kulturno geografijo Univerze v Frankfurtu, od 13. - 15. aprila 1999 v Ljubljani, je bil namenjen predstavitvi najnovejših procesov v mestih. Okrog 50 udeležencev je poslušalo 12 referatov petih tujih in sedmih domačih geografov. Zadnji dan je bil namenjen strokovni ekskurziji v Vzhodno Slovenijo in obisku Velenja, Maribora in Ptuja.

Kot na večini podobnih strokovnih srečanj so bili referati kolegov iz Frankfurta strogo naravnani na obravnavo mestne problematike, slovenski pa, med katerimi sta poleg sodelavcev Oddelka za geografijo poročala tudi predstavnika Inštituta za geografijo in Ministrstva za okolje in prostor RS, so predstavili tudi širšo regionalno-razvojno problematiko. Po uvodnem referatu Klausa Wolfa o novih izhodiščih geografskih proučevanje povezanih z globalizacijo in regionalizacijo je sledila izredno aktualna problematika procesov razvoja in preobrazbe mest in mestnih območij v regiji Ren - Maina, ki je tudi temeljno raziskovalno področje nemških kolegov. Glede na dominantnost Frankfurta kot enega razvojno najživahnejših evropskih središč so urbanizacijski in razvojni procesi na sploh izredno živahni in konfliktni. Referati so obravnavali naslednje vsebine: perspektivo regionalnih upravnih struktur, regionalno identiteto "Global Village", omrežje mest kot perspektiva medobčinskega sodelovanja in problematiko robnih zgostitvenih območij "Speckgürtel".

Slovenski referenti so predstavili problematiko oblikovanja mestnih regij, vplive globalizacije na razvoj slovenskih mest, regionalno razvojno problematiko Slovenije, ubranost fizične strukture slovenskih mest, socialnogeografsko preobrazbo Ljubljane, oskrbno ifrastrukturo kot dejavnik omrežja slovenskih mest in razlike $\mathrm{v}$ življenjski ravni med urbanim, suburbanim in ruralnim prostorom. Podobno kot vsa dosedanja podobna srečanja s težiščno problematiko o urbanem prostoru, je tudi ta seminar pritegnil veliko strokovne pozornosti, saj pomeni z izredno aktualnimi referati in razpravami o Frankfurtski urbani regiji najkrajšo pot k spoznavanju razvojnih procesov in oblik njihovega proučevanja. Referati so tiskani $v$ reviji DELA 14.

Organizacijo seminarja so omogočili Ministrstvo za šolstvo, znanost in šport, Urad za okolje in prostor Ministrstva za okolje in prostor RS, OddeleK za urbanizem in okolje MOL, Mestna Občina Ptuj in Kmetijska srednja šola Ptuj.

Mirko Pak 